\title{
DOI https://doi.org/10.30525/978-9934-26-042-1-5
}

\section{ЦИФРОВИЗАЦИЯ СОЦИАЛЬНОГО ПРОСТРАНСТВА И КАЧЕСТВО ОБЩЕСТВЕННЫХ КОММУНИКАЦИЙ}

\author{
Шедяков В. Е. \\ доктор социологических наук, \\ независимый исследователь \\ г. Киев, Украина
}

Заграждены уста твоим пророкам И слово вольное дано твоим ослам.

В. С. Соловьёв

Виртуальные миры не только множатся, подчас заслоняя реальность, но и, порой, выступают орудием её поражения и искажения. А при помощи общественных коммуникаций можно не только так или иначе передавать отношения, но и создавать их. Речь идёт уже об активном участии в трансформациях и самих культурноцивилизационных миров, и их ценностно-смысловых комплексов. Соответственно, качество социального пространства (в частности, его иммунитет) испытывается на прочность и коммуникативной открытостью, и информационным напором [1-5].

«Цифровизация» несёт с собой сбор и аккумулирование гигантского объёма информации. Причём в информационно-цифровых ТНК, которые (в противовес государственным персонам) не подвержены народному контролю, управляются отнюдь не соответственно воле народа и где кадровая политика и курс вовсе не ориентированы на мнение народа. Вопреки, с одной стороны, свободе слова и правам человека, с другой, - народному суверенитету в «цифровом мире» (в частности, и в социальных сетях) может поддаваться цензурированию всё, противостоящее навязываемому мейнстриму, глуша творческое разнообразие ойкумены.

T.о. многие из измерений «цифрового мира» чрезвычайно остро ставят перед ойкуменой новые социально-экономические, а то и политические проблемы. Начиная от «теневого Интернета» и расширения возможностей содействия терроризму вплоть до потока влияния на происходящее и подготовки будущего. Воздействие «цифрового мира» предоставляет богатые ресурсы и в конкурентной борьбе, и в 
осуществлении власти. При этом, с одной стороны, социальные сети привлекли в число «властителей дум» массу обычных неподготовленных и обладающих ограниченной компетентностью обывателей (которые именно простотой своих оценок и близки воспринимающим), с другой, осуществилась высокая степень централизации собственности-власти над каналами информирования и обмена мыслями. Как один из результатов, смена консервативной волны либерально-социалистической группировкой во власти в одной из могущественных федераций произошла в т.ч. и $\mathrm{c}$ опорой на монополию информирования (и односторонность освещения событий), уличные движения, анархоориентированную молодёжь и расовых экстремистов.

Между тем, надо учесть объективную необходимость при усилении тенденций формирования в глобальном масштабе общества знания и расширения круга потребностей, связанных с доступностью высококачественного образования и медицины, заинтересованность государств в случае их высоких притязаний и целевых ориентаций в приоритетном росте качества человеческого потенциала и создании условий развёртывания и реализации одарённости каждого в просоциальном творчестве. Тогда как социальные сети могут служить как усреднению, так и болезненному самовыделению и эгоцентризму [6-9]. Среди вопросов, не решаемых в прежней общественной «системе координат», наиболее важны для всей ойкумены в устройстве внутренней жизни - проблемы обобществления (прежде всего, диффузии системообразующих отношений труда, собственности и управления) и максимизации поля просоциального творчества, внешней - преодоление раскола на химеричный «мировой центр» и «остальных». Знание же, опыт, квалификация и т.п. заведомо рассеяны в обществе - так же, как и дарования. Вместе с тем, если Модерн приучил к оптимизации развития за счёт унификации модели жизнедеятельности, то разнообразие черт постмодерна (соответственно, постглобальности, постиндустриальности и т.д.) ориентирует на принципиальное несовпадение подходов. Теперь конкуренция разноуровневых регионов - это состязание моделей: чем выше своеобразие модели, тем легче и полнее можно учесть особенности условий, среды, ценностно-смысловых комплексов, ментальных матриц, наращивая конкурентные преимущества и сокращая роковые риски.

Способность к устойчивости и изменению культурно-цивилизационных миров во многом определяется сплетённостью (в частности, под влиянием исторического опыта и социокультурного наследия) объективных и субъективных факторов структурирования, формирующих разнокачественные обратные связи и отношение к творчеству (индивидуальному и массовому, в труде и управлении). Эффективное 24 
отстаивание национальных интересов невозможно как вне ограждения информационного пространства от наиболее гибельных информационных вирусов, так и без системного укрепления информационного иммунитета (в частности, культивирования и развития на отечественной основе ценностно-смысловых комплексов культурно-цивилизационных миров), - что, разумеется отнюдь не отрицает гибкости и восприимчивости по отношению к полезным инновациям. Прорыв к высотам общества знания естественно предполагает как укрепление подлинного суверенитета, так и последовательные народовластие и децентрализацию (то и другое основано на высокой сознательности для грамотной самоорганизации и качественного самоуправления). Напротив, полицейское государство (часто - c опорой на силовой блок, нагнетанием пропагандистской истерии вместо аналитики, подменой понимания происходящего удобными жупелами, тоталитаризмом, дополняемым экстремизмом и слабостью парламентаризма, непрофессиональностью, необъективностью и ангажированностью СМИ) и финансовый олигархат как форма унии компрадорской буржуазии и коррумпированного чиновничества прекрасно дополняют друг друга, провоцируя торжество классического бонапартизма с колебаниями между векторами давления влиятельных сил и дальнейшую балканизацию и атомизацию общества. Для всякой «идеологии Сильной Руки» свойственно манипулятивное начало, принижающее человеческое достоинство и ведущее к оболваниванию масс. Тяга к нему усиливает линии раскола между народом и власть имущими. Между тем, в людях сильно доброе начало, берущее верх всякий раз, когда под угрозой как развитие, так и безопасность образа жизни людей в культурноцивилизационных мирах. Удовлетворение основных потребностей человека: в уважении, достоинстве, свободе выбора, праве на жизнь и творчество - при переходе к экономике знания так же неотъемлемо, как государственные гарантии роста качества материальной и духовной обеспеченности каждого [10-12].

\section{Литература:}

1. Назаров М.М. Массовая коммуникация и общество. Введение в теорию исследования. Москва: Аванти плюс, 2003. 428 с.

2. Newman R., Guggenheim L. The evolution of Media Effects Theory: A Six-Stage Model of Cumulative Research. Communication Theory. 2011. № 21. P. 169-196.

3. Ивентьев С.И. Божественные и духовно-нравственные права и свободы человека. Новосибирск: СИБПРИНТ, 2012. 357 с. 
4. Шедяков В.С. Стратегічне управління процесами постсучасних трансформацій за допомогою інформаційних впливів соціальнополітичного рівня. Вісник Дніпропетровського університету. Філософія. Соціологія. Політологія. 2015. № 1 (23). С. 248-259.

5. Shedyakov V. Social technologies and communications: basic trends of changes. Scientific Development of New Eastern Europe: Proceed. of Intern. Scient. Conf. Riga, 2019. Part I. P. 128-130. DOI: https://doi.org/10.30525/978-9934-571-89-3_45

6. Шедяков В.Е. Рефлексивная модернизация и социальная педагогика: дрейф общественных коммуникаций. Соціальні технології: актуальні проблеми теорії та практики. 2020. Вип. 86. С. 187-200. DOI https://doi.org/10.32840/2707-9147.2020.86.17

7. Шедяков В.Е. Стратегии социальных коммуникаций: быть или манипулировать. Key Issues of Education and Sciences: Development Prospects for Ukraine and Poland: Proceed. of Intern. Conf. Stalowa Wola, 2018. Vol. 2. P. 172-174.

8. Шедяков В.Е. Выбор стратегии использования социальных коммуникаций: cui prodest. Strategic Management: Global Trends and National Peculiarities / ed. by A. Pawlik, K. Shaposhnykov. Kielce: Baltija Publishing, 2019. P. 254-266.

9. Шедяков В.Е. Развитие социальных коммуникаций в конкуренции культурно-цивилизационных миров. Актуальні проблеми соиіальних комунікацій: Матер. Міжнар. наук.-практ. конф. Запоріжжя, 2020. C. $60-64$.

10. Шедяков В.Е. Возможности и угрозы для творческой реализации человека в сетевом обществе. Development of Socio-Economic Systems in a Global Network Environment: Proceed. of Intern. Scient. Conf. Le Mans, 2020. P. 88-90.

11. Шедяков В.Е. Медийный фактор в жизни человека и общества. Virtus. 2020. Issue 45. June. P. 252-256.

12. Шедяков В.Е. Медийный фактор при виртуализации жизни. Virtus. 2020. Issue 47. October. P. 135-140. 